\title{
Sheila Ribeiro
}

\section{ABSURD CONGRUENCIES}

APRJA Volume 2, Issue 1, 2013

ISSN 2245-7755

CC license: ‘Attribution-NonCommercial-ShareAlike’. 


\section{Facing some facts}

Bruce Springsteen was invited by the mayor of Naples to inaugurate a significant movie theatre in the city. So it was published in local newspapers as, for instance, Napoli Reppublica. Some citizens of Naples thought the idea rather absurd and complained frustratedly, feeling impotent with the fact. Is it Mr. Springsteen's fault? Is the mayor's choice untactful? How responsible is the movie theatre for that choice? Is it really happening in Naples?

Mleeta is a war theme amusement park. Run by the Hezbollah, it is both a touristic leisure option for local families and a questionable event for non-locals. Mleeta is understood as a normalized atraction in Lebanon. A sightseeing spot for war. Scary, right? How amazing is a park in which one might rebuild local identities and culture! Mleeta is located in South Lebanon. Mleeta is located alongside the Israel/Palestine conflict. Mleeta is 09/11, it is Osama Bin Laden's and Saddam Hussein's death and murder. Is Mleeta about amusement? Is Mleeta about war? Can war and amusement be related? Well, we know they can. We have seen it in games, on the news, and authors have extensively analyzed this connection. However, it had never been as explicit as in this theme park.

Then, we are introduced to INRI Cristo, a Jesus Christ aspirant, who re-elaborates musical video clips. His crew remakes Britney Spears, Rihanna and Amy Winehouse - to mention just a few divas. Is he delusional? YouTube has been a potent platform for designing glocal identities. But, how do all these Anglophone female pop singers end up in his remakes?

What do the three facts above have to do with one another? Well, they are and are not bizarre. They emerge as events of digital cultures (Badiou). Made with, coming from, as well as being glocal biopolitical tensions and communication, they become communication themselves and reveal new values and contemporary traces - the very same that shape them as mediabodies, i.e., each and every one of those events manifests a trans glocal matter.

Reverberating on crossed dimensions, in the Mediabody Theory the concept of "body" is a system of constant dialogues with environments in which human bodies take a part, but are not the central agents anymore (KATZ\&GREINER, 2006). The absurd congruences above are mediabodies of an ongoing flux of changes.

\section{Emerging communicational processes}

The facts described above are communicational events and still have not been completely identified neither properly approached. They are phenomena of microtensions, coming from macrotensions. They are expressed in varied formats (people, ads, billboards, flyers, dresscodes, networks) as contamination spreads out and proliferates into several unequitable ways, which regulate the production of absurd congruencies. These sparkling and infiltranting ways of crossed contamination, a trans way, scratch bodies regulating the modus operandi and later camouflage into normality.

They are constituted more of contemporary political and cultural cognitive tensions and constructions than necessarily (and properly) their form-content specificity. They are both symptom and system.

It really does not matter if it manifests itself in fashion, architecture, performance, advertising, musical video-clips etc. because in the absurd congruence the media is no 
longer the most important parameter, but rather the way through which mediation has been passing (a system): "to the extent that the announcement does not refer to a text but to a vivid language event (...), its territory would never match a defined level of linguistic analysis (...) nevertheless it constitutes much more a function" (AGAMBEN, 2008: 141). Furthermore, once mediation has become its own subject (a symptom) and is a kind of mediation phenomena, then, in theory, to approach the absurd congruence one has to switch "from media to mediation" (Martin-Barbero).

No "starting point". No development. No end. No distinct "object". No distinct "subjectobject" (a system and a symptom). The absurd congruence, as mediation, as a mediabody of transcommunicational processes, carries traces of contemporary capitalism: it is a system-symptom. Thus, the absurd congruence emerges as contemporary glocal sensitivities while becoming a mediabody of ongoing glocal geopolitics. "... the glocal represents the way in which capital (...) falls promptly in each dome, in every workplace, in every locus private or public, so all transformed into functional support of an imagecircularity informational absolute billionaire and ad infinitum." (Trivinho, A dromocracia cibercultural 261).

Communication phenomena have been permeating contemporary new desires and sects while glocality elevates its more relevant cultural and communicational events: "The category of glocal sheds light on an infinite series of phenomena, events, practices, processes and current trends" (Trivinho, A dromocracia cibercultural 324). If "real time is a time-that-fades well done caricature", the glocal mediabody is a self-rebuilt-symbolicspace-time sort of caricature. It is an imbrication of contrasting processes; obliteration; changing and preservation (Trivinho, A dromocracia cibercultural). Their expressions seem to be made from a mix of apparently distinct elements. However, those elements cannot really be considered distinct because the equality and distinction parameter depends on a very specific epistemology that does not fulfill contemporary realities anymore. They would be incongruent within their environment only if origin and land could be named, only if they were analog and societarian, only if one sole epistemology existed. But, instead they are bodies emerging from the digital culture of heterocontamination, i.e., communication embracing analogical traditions, costumes and habits. Their realm turns out to be concomitant consequences or incidental phenomena, so to speak. On treating the absurd congruencies, these supposedly lateral events manifest themlseves in different formats, in a tangential way as a part of contemporary analog-digital glocal realities, whereas in glocal displacement signs have multiple, complex and upside-down literacy, as well as starting points other than its own, that is, mutable multiple starting points.

The absurd congruencies, as events, are metropolitan choreographies with their own aesthetic context, sometimes with costumes, performers, location, script, scenario, technique, time-space and language. Their authorship is no longer precise, and although it could be guessed, no one is specifically implied.

Let us now consider digital cultures taking Native, an organic food brand, as example. Its cookies are wrapped twice: they come in a big "Amazonian" green package (one) that contains three small aluminum bags (two). Could they ever be sustainable? It is a native, who comes from a factory, from a nutritionist's recipebook, from officially "ecocertified" and environmentally conscious institutions, from designers and advertising campaigns. Where could it be native from? The only possible "native" today is the communicational mediabody. 
Glocalism draws both from origin as well as from the global mediatic traces. Thus, on one hand, its signs refer to belonging. They reaffirm a clearly known, fixed identity: the will to reproduce a hint of "authenticity", things, values and references that claim to be culturally incorrupted, as if the reproduction of signs could ever maintain their specific constitution intact. On the desire level at least, belonging ensures a comfortable belief in a stable geographic territoriality: "roots" (rooted ones). Nevertheless, a genuine "nonalien-self" is rebuilt. On the other hand, the absurd congruence is a complete reinvention and, by being so, is part of a "global community", not the analog, but the analogdigital one. This community transits among several displacements (loss and fear) while neocapitalism forces and imposes fluxes, transits, and multiple "métisse" selves. Thus, the identified phenomena could only be considered incongruent through a dichotomic epistemology and by being viewed as "glocal is obliteration" (Trivinho, A dromocracia cibercultural 273). It runs through, pierces and surpasses fetishistic complexities, facing rising communicational processes and becoming a new kind of "native" - no longer from an analogic composition. Thus, the mediabody of the analog-digital results from contemporary dynamics and communication.

Beyond any precise form of boundary, guide or landmark (no land and no mark), nothing else can distinguish itself because we are talking about samples of both complex interconnected realities except for the immaterial parameters of the absurd congruence of contemporary capitalism. Fathoming these samples of apparent incongruity can be a key to understand post-dichotomic cultures.

\section{Analog-digital mediabodies as glocal communicational metropolis}

Coming from the Mediabody Theory (KATZ \& GREINER, 2006), the absurd congruence is a mediabody, i.e., a system. In this theory, each and every body is a collection of information in constant codependent dialogue with the environment, being both process and state:

The body is not a means by which information simply passes. Any new information enters into negotiation with those already there. The body is the result of these crossings and not a place where information is just housed. It is with this notion of the itself media that the Mediabody Theory deals, not with the idea of media designed as a vehicle of transmission. The media to which the Mediabody Theory refers relates to the evolutionary process of selecting information that will constitute the body. The information is transmitted in the process of contamination (Katz and Greiner, "Por uma teoria do corpomídia“131).

Things are not centered in the body, but are latent in a mediabody which is porous, symptomatic, circumstantial. In this sense, it is something of an amorphous mediabody. It is latency and organization of all kinds of movable materials. Because there is no central body acting, all objects have that function. What exists is a body in the gerund because of the continuous flow of processing.

As an "itself media", the mediabody announces the environment-body in a flux of permanent porosities and all-vectorial mutations:

Some information of the world is selected to be organized in the form of the body - a process always conditioned by the understanding that the body is not a 
container, but what it is turning into at this co-evolutionary process of exchanges with the environment. And since the flow does not stagnate, the body lives in the state of an ever present, which prevents the notion of the body as a container. The body is not a place where the information coming from the world is processed for later returned to the world (Katz and Greiner, "Por uma teoria do corpomídia“ 64).

The absurd congruence is post-dichotomy geopolitics. It is a trans matter analogdigital mediabody in a constant dialogue with what digital cultures have been producing and training as perceptual behavior of things, bodies, congruencies. It is a communicational metropolis (Canevacci, Una stupita fatticitá) in an imbrication of contrasting processes; running through dimensions of glocal sensitivities. The absurd congruence is mainly tension coming from and living throughout the triad communication-culture-consumption:

The difference between the city and the modern industrial metropolis is increasingly characterized by the diffusion of the triptych communication-culture-consumption. Communication is increasingly determining the configuration and features of this kind of metropolis in which the concept of historical society loses strength with changes, innovations, conflicts and tensions. This metropolis is beyond any industrial dualism (Canevacci, Una stupita fatticitá 120).

When we observe Canevacci's concept of the communicational metropolis, we can immediately relate it to the mediabody theory, as location and bodyscape are both its mediabodies, mediabodying as and through the flux, signs, tensions, vectors, escapes...

Location: place-space, zone, interstices (Canevacci, Una stupita fatticitá 32).

Bodyscape is the panoramic body that floats between the interstices of the communicational metropolis. The suffix "scape" joins "body" in order to accentuate the floating concept of the body, which extends the itself and others observation - while being dense fetishistic codes' visual panorama (Canevacci, Una stupita fatticitá 30).

The absurd congruence is glocalization, and more than the body of a time and space dissolution, it is a remix of cognitive tensions, loitering on the intermediations of contemporary capitalism. These intermediations infiltrate the private or public locus, moving across land and territory (analog and dialectic), as well as floating and combusting the non-cartographic flux of the communicational metropolis, and finally establishing itself as communication. Pulsing this glocal multividuality (Canevacci, Una stupita fatticitá) at the analog-digital, this phenomena is both extension and expansion.

\section{Identifying an absurd congruence:}

- It is a communicational event that is somehow both a cognitive combination and a consequence;

- It is visibly glocal, analog and digital, industrial and post-industrial;

- It astonishes for its apparent incongruence;

- It is normalized locally, but considered globally weird;

- In spite of its strangeness, it is not exotic. It is an accepted "locally-born stranger". Thus, an absurd congruence is completely normalized, infiltrated, almost invisible as if it were not there. It is the bizarre unrealized and for being so it is accepted;

- It is not clear, but it is not ambiguous: neither dichotomy, nor non-dichotomy. It is not a dualist event. But, it turns out to make complete sense once it 
is seen through analog-digital glocal tensions and parameters;

- Its codes cannot be considered pure or impure. It has no precise origin, no clear destination, nor destiny.

- It is an ongoing mutation and preservation; it is the native and the other;

- Its authorship is undefined;

- It is a symptomatic cacophony.

It is emblematic and imprecise signal constructions manifested within microphysics that reveal contemporary glocal sensitivities, new values and traces;

- It belongs to the contemporary power mutations and reveals new contemporary traces;

- It is nondefinitive and incomplete: even though it is an overwhelming phenomenon, its partiality seems to bring an event that is both abundant and precarious;

- Although humans are a part of it, they are no longer its center, nor do they interfere with its cognitive decisions autonomously. The human body has been decentered. It is just one more thing, one more thinking-thing thing, as autonomous as any other non-thinking-thing;

- It is cognitive vectors and realities established by the mediabody (and disestablished?) and these are built throughout and "trans-upon" human awareness.

\section{Starting trans}

Perspicuity and certitude would not fulfill a research based on the states of itinerant contemporary capitalism, particularly, on how the communicational politics of capitalism manifest themselves in all the several communication mediations. Then, one must float while creating new methodologies in order to contribute to the rising of a needed roaming epistemology.

Without a pinpointed origin and dealing with partially accessible realities, contemporary glocal communicational power relations do not follow the intelligibility of totalitarian or authoritarian parameters. There is no visible torture, no visible killing, no visible retaliation. However, they rule untouchable and imprecise parameters and evolve into expanded and decentered perversions, i.e., "near tortures", "in-between retaliations" and "possibly killing" modes. That is when, once again, we detect the impertinence of dialectics as the dialectical parameter deals with dichotomy, double, extremes and a causeand-consequence equation, distinguished dimensions and uncrossed ones. In dialects we have confrontation and comparison, and the parameters mentioned above do not meet the needs of the trans. Contemporary glocal communicational power relations indicate circumstances, while a transresearch might be an indication, may those adverbs which now accompany contemporary dimension have to do with trans and for something trans that happens.

As we face analog-digital cognitive tensions, would it be possible to escape from the dialogic of the dual analog/digital and sit on the hyphen? And if so, could this hyphen, an orthographic tension of only two worlds, make links as a non-linear multidirectional and multidimensional vector partially tensing diverse realities would? The hyphen as interstitial data (Canevacci, Una stupita fatticitá), as the main mediabody.

The absurd congruence is a trans event. It flickers from a maybe, to a yet, and then an almost. The absurd congruence still is at the while it never will be. There are no valuable actions, no verbs. It is totally 
unclear, like neocapitalism. This mediabody is also circumstantial. There is no able discipline neither is there an indiscipline available to research an "adverbial reality".

Therefore, this might be how and when apparent dispersions bring ways of operating in the contemporary realities. What disciplines would deal with tensions and vectors? Would contemporary realities take new methods? New epistemologies? An adiscipline? Would new methods be possible within the current academic fields?

Dialectics cannot resolve trans realities because they lack the concrete oppositions which are crucial for the dialectical debate. There is no compass that could work for transrealities. Trans promotes impossible passages that pass things through. What would the methodology for impossible passages be? How approach the enhancement of intersections flyovers, broken upside-down equations? Is this methodology lockable from its bodies' dialogics? Is there an inside in a partial, uncertain, confusing and imprecise event such as the absurd congruence? Would this decentered rhizomatic thinking inspire contemporary trans epistemologies to deal with trans at the same time it ensures to stay away from the logics of dialectics? How to face itinerant approaches, itinerant thinking (which first has to be acknowledged as legitimate)? How to avoid being trapped into dialectical epistemologies?

In order to approach complex interstitial events still partially identified, an epistemology has to disable pertinence or legitimacy, which predetermine whether something is "worth being looked at" as, for instance, old fashion pop-ups. They are not much fancied anymore, but although they have been blocked and regarded as illegitimate, they still exist in a hidden form.

An epistemological frame could not go backwards and decide whether an event exists. Thus, it has to identify apparent inconsistencies, mutations, sobbings, stumbling and deformations. The approach of incidental, invisible and interstitial contemporary events needs no grabbing, no comparison, but some description. It should instead highlight the crossings as it creates tools to realize its impossible crossings, focusing on cognitive tensions. In order to deal with these phenomena, it has to consider apparent incongruity as legitimate. Therefore, a possible epistemology has to embrace fuzzy logics considering complex elements as research material, including writing, visual and sonic ones, and crossed mimetics multiple views. A risky epistemology for risky realities: getting lost, floating, navigating and displacing as a methodology.

It must have the ability to weave into the "in between", the "still", and to pass through the adverbial equations, geometries and indescribable actual configurations, without turning them away as if they were invisible and "not worth looking at".

Astonishment might not be enough to approach symptom-system events anymore. A foreign mediabody epistemology might be established inside itself and discuss its own demonstrations, i.e, a foreign epistemology is foreigner as long as it belongs to transits and their cognitive tensions. Then, its parameters find themselves into other porous, mutable, crossed-over and unstable parameters - not central ones. A foreign epistemology is an adverbial mediabody. Therefore, it is an epistemology that samples as it becomes samples itself. 


\section{Works cited}

Abrantes, P. org. Epistemologia e cognição. Editora UnB, 1993.

Appadurai, A. (ed). The social life of things: commodities in cultural perspective.

Cambridge: University Press, 1986.

Badiou, A. L'être et l'événement, Éditions du Seuil, 1988.

Benjamin, W. L'opera d'arte nell'epoca della sua riproducibiltà tecnica. Torino: Einaudi, 1966.

Bhabha, $\mathrm{H}$. The Location of Culture. London: Routledge Classics, 1994.

Boyd, B. On the Origin of Stories. Evolution, Cognition, and Fiction. The Belknap Press of Harvard University Press, 2009.

Campbell, $\mathrm{H}$. "The rise and rise of EurepGAP: European (re) invention of colonial food relations", International Journal of Sociology of Food and Agriculture 13 1-19, 2005.

. Liepins R. "Naming organics: understanding organic standards" in New Zealand as a discursive field - Sociologia Ruralis 41 22-39, 2002.

Canclini, N. La globalización imaginada. Barcelona: Paidós, 1999.

Canevacci, M. Fetichismos Visuais - corpos erópticos e metrópole comunicacional. São Paulo: Atelier, 2008. . Comunicação visual. São Paulo: Brasiliense, 2010.
. "Digital Auratic Reproducibility:

Ubiquitous Ethnographies and

Communicational Metropolis", in: An

Ethnography of Global Landscapes and Corridors. InTech Publisher, 2012.

. Una stupita fatticità. Feticismi

visuali tra corpi e metropoli, Costa \& Nolan, 2007.

Chemero, A. Radical Embodied Cagnitive Science. Cambridge, MA: The MIT Press, 2009.

Churchland, P S. Braintrust. Princeton University Press, 2011.

Cosgrave, D. "Prospect, perspective and the evolution of the landscape idea", Transactions of the Institute of British Geographers, New Series $1045^{\wedge}$ 62, 1985.

Dicks, B and Mason, B. "The digital ethnographer", Issue Six: Research Methodology Online, www.cybersociology.com/ files/6_1_virtualethnographer.html Esposito, Roberto. Bios. Biopolitics and Philosophy, University of Minnesota Press, 2004.

Fanon, F. A Dying Colonialism. New York: Montly Reviews Press, 1965.

Freidberg, S. Commentary. Perspective and power in the ethical foodscape Environment and Planning A 42 1868-1874, 2010.

Garcia, R. Micropoliticas del Cuerpo. Latitud Sur, 2000.

Gleick, J. The Information. A History. A Theory. A Flood. New York: Phanteon Books, 2011. 
GlobalGAP, What is GLOBALGAP?", GLOBALGAP, Cologne, http://www. globalgap.org/, 2008.

Greiner, C. O corpo em crise: novas pistas e o curto-circuito das representações. São Paulo: Annablume, 2010.

. O corpo: pistas para estudos indisciplinares. São Paulo: Annablume, 2005.

Haraway, D. Simians, Cyborgs and Women: The Reinvention of Nature. London: Free Association Books, 1991.

Hess, J. Reconstituting the Body Politics. Enlightment, Public Culture and the Invention of Aesthetic Autonomy. Wayne State University Press, 1999.

INRI CRISTO. "Britney Spears Versão Mística de Toxic": http://www.youtube.com/ watch?v=XSOktNjpqpY. Web

Katz, $\mathrm{H}$ and Greiner, C. Corpo e Processo de Comunicação. Revista Fronteiras Estudos Midiáticos, Vol. III, N² 2, , pg. 65 - 75, em www.helenakatz.pro.br, 2001.

Por uma teoria do corpomídia. In: GREINER, Christine. O corpo: Pistas para estudos indisciplinares. São Paulo: Annablume, 2005.

Lang, T. From value-for-money' to valuesfor-money'? Ethical food and policy in Europe, in Environment and Planning A, volume 42, 2010.

Martin-Barbero, J. Dos meios às mediações: comunicação, cultura e hegemonia. 2.ed. Rio de Janeiro: Ed. da UFRJ, 2003.
Martins, F. and Machado da Silva, J., orgs. A Genealogia do Vitual. Comunicação, Cultura e Tecnologias do Imaginário. Porto Alegre: Sulina, 2004.

McLuhan, E. (ed.). Marshall McLuhan Unbound, Vol. I. CA: Gingko Press, 2005.

McLuhan, M. War and Peace in the Global Village. New York: Bantam Books, 1968.

McLuhan, S. and Staines, D. (eds). Understanding Me: Lectures \& Interviews. Cambridge, MA: The MIT Press, 2003.

Menary, R. The Extended Mind. The MIT Press, 2010.

Mleeta: www.mleeta.com/

Native: http://www.nativealimentos.com.br/. Web

Olinto, H. and Schollhammer, K.. Novas Epistemologias. Desafios para a Universidade do Futuro. Nau Editora, 1999.

Ranciére, J. O Desentendimento. Política e Filosofia. Editora 34, 1996.

Robins, $\mathrm{K}$ and Webster, F. Times of the tecnoculture: from the information society. London; New York: Routledge, 1999.

Rose, Nikolas. The Politics of Life Itself. Biomedicine, Power, and Objectivity in the Twenty-First Century. Pirnceton university Press, 2007.

Said, E. Orientalism. New York: Vintage, 1979.

Santos, B. and Meneses, M. org.

Epistemologias do Sul. São Paulo: Cortez Editora, 2010. 
. org. Another Knowledge is

Possible. Beyond Northern Epistemologies, Verso, 2007.

Sebeok, T. Communication Measures to Bridge Ten Millennia. Ohio: Battelle Memorial Institute, Office of Nuclear Waste Isolation, 1984.

Shapiro, L. Embodied Cognition. New York: Routledge, 2011.

Spears, Britney. "Toxic (Official Music Video)": http://www.youtube.com/ watch?v=yoJIn6oSjJE. Web

Sunder Rajan, K. Biocapital. The constitution of Postgenomic Life. Duke University Press, 2006.

Tancredi, L. Hardwired Behavior. What Neuroscience Reveals about Morality. Cambridge University Press, 2005.

Trivinho, E. O mal-estar da teoria: a condição da crítica na sociedade tecnológica atual. Rio de Janeiro: Quartet, 2001.

. A dromocracia cibercultural: lógica da vida humana na civilização mediática avançada. São Paulo: Paulus, 2007.

. Bunker glocal: configuração

majoritária sutil do imaginário mediático contemporâneo e militarização imperceptível da vida cotidiana, em Comunicação, mídia e consumo. São Paulo, vol. 5, n.12, p. $11-34$, março, 2008. 


\section{Andrew Prior}

\section{GLITCHING PARALOGY}

APRJA Volume 2, Issue 1, 2013

ISSN 2245-7755

CC license: ‘Attribution-NonCommercial-ShareAlike’. 
Is research today occupied more with mundane acts of recategorisation, and - after Bologna - with what Lyotard already called performativity? Or does it still engage the kind of marvel and wonder that so many ascribe to Pluto and that BWPWAP captures as a cultural term? (Transmediale)

\section{Abstract}

In the late seventies, Lyotard claimed that research and culture would be increasingly legitimated not on their own terms, but through their performance in supporting the smooth running of governmental, economic and bureaucratic systems; treating them as inputs and outputs in the production of power, something he referred to as 'performativity' (xxiv).

He suggested a 'paralogical' approach to offset this tendency, which broadly meant pursuing those kinds of research and culture that highlight and de-stabilise underlying systemic conditions, and that critique, or change the rules of such systems. This paper suggests that glitch-art practices constitute a vibrant 'paralogical' response to a performativity within arts and research, though this is not to say that they are, de facto, immune to it. The argument contends that $t(h)$ inkering (Huhtamo), DIY and heuristic strategies provide a useful way forward in critiquing and sustaining glitch paralogies.

\section{Knowledge and Performativity}

Although the epithet of postmodernism now feels distant and somewhat stale, we have not yet experienced any clear break with it, (Varnelis) indeed many of the concepts around which it was formulated hold true now more than ever - the distrust of meta-narratives; the championing of plurality; subjectivity, contingency and context; the problems of authorship and originality... these issues remain today, though are perhaps thought of as truisms, stable enough to be considered done-to-death within academia.

Reading Lyotard's 'The Postmodern Condition: A Report on Knowledge' today however, one is struck by its prognostic accuracy. In it, one of Lyotard's key arguments was that the cybernetic characteristics of contemporary culture legitimate knowledge not for its own sake, but for its performance. His claim suggests that the world of ideas and aesthetics is no longer valued in itself, warning that their institutionalisation, or at least the changing qualities of institutions, might drain them of meaning.

It is interesting to note the central role accorded to cybernetics in this argument. The wide applicability of cybernetics has been due to its emphasis on systems over content: biology, economics, weapons, ecology and many other fields, might all be thought of as network structures of control and feedback; interlinking operations and transformations of signals and messages. Accordingly, Lyotard's notion of performativity (which he draws from Niklas Luhman and Jürgen Habermas) implies performative legitimation is granted not on the inherent qualities of research, practice, education etc. but on their ability to produce maximal results by minimal means, for the upkeep of the system they exist within. (Halbert 1)

The systems emphasis of cybernetic thinking took its cue from information theory, and one can note parallels between performativity and the qualities ascribed to information within this field. Key to the development of information theory was the 
conceptualisation of information as quantity without semantic meaning, of interest solely in engineering or mathematical terms. Similarly, the issue with performativity is that it ignores the content of research, education, science and the arts, in favour of their ability to perform and produce results. As Terranova has argued, our culture has been dubbed informational not simply because of the vast morass of information we now live with, but also because the characteristic dynamics of information now impact upon all spheres of contemporary life. (7) In discussion around politics, business, education and other fields Terranova suggests:

Communication management today increasingly involves the reduction of all meaning to replicable information-that is, to a redundancy or frequency that can be successfully copied across varied communication milieus with minimum alterations. (57)

Legitimation through performativity can be seen as a natural result of the increasingly informational and networked quality of a post-industrial context. Perhaps the key problem for Lyotard is the assumption that knowledge can undergo a translation into something that suits systematisation, without in itself being changed irrevocably: that it is commensurable with the systems which use it in the production of power. It might be argued that the informational, performative emphasis within research and culture leads to a flattening out and instrumentalisation of socio-cultural processes, grounded in the smooth running of the system, rather than in meaning for it's own sake. Such an approach ignores detail, grain, and interest - favouring the paths of least resistance.

On the other hand, Lyotard suggested (perhaps somewhat provocatively) that even performativity has positives: including its emphasis on transparency, it's predictability and broadly speaking, its efficiency. (op.cit. 62) In the recent climate of economic austerity, such characteristics take on new significance, though as a characteristic of post-industrial society, performativity has, of course, been on the rise for many years. Broadly speaking, performativity is a fact of life within postindustrial, informational culture and as such, here to stay. The challenge then, rests in how it is dealt with - and here Lyotard suggests a typically post-modern move.

\section{Paralogy}

'Paralogy' as an alternate mode of legitimation to that of performativity. Lyotard uses the term to refer to legitimating discourses that: explore paradoxes and anomalies; foreground the critique and destabilisation of existing methodologies; create new methodologies; and that disrupt the Habermasien notion of 'consensus community'. Habermas felt that 'legitimacy [was] to be found in consensus obtained through discussion', (Lyotard op.cit. xxv) which Lyotard sees as problematic, as it flattens diversity and difference. (Halbert op.cit. 2) Paralogy is therefore an approach that favours dynamic tensions and heterogeneity over operativity and consensus. It is the bending of rules, the creation of new rules, and a self-reflexive awareness of the rules that govern research and culture.

It must be said at this point that performative and paralogical legitimation are not mutually exclusive: research might be in the best interest of the institution even whilst it is critically aware; artistic processes may be antagonistic and self-reflexive and nevertheless benefit the systems of legitimation they exist within - for example through incorporation into art markets, festival circuits, commercial products, the language of film, television and music. Moreover, paralogy need not be confined to the arts. For Lyotard it can be used across disciplinary boundaries and beyond 
academic contexts. One might say that in any given field it reverses the cybernetic model, foregrounding the specifics and granularity of knowledge over its systemic characteristics.

\section{Glitch practices}

Glitch practices are interesting in this respect as they often concern themselves with systems at the point of failure: communications, software, media technologies - systemic materials at the moment they collapse into granularity and difference. Therefore glitch art might constitute a paralogous approach in drawing our attention to the materiality of its media, the conditions of technology and the constructed character of aesthetics. In hacking, bending, and repurposing they are changing the rules of the systems they exist within; simultaneously helping us better understand the conditions of technology, and suggesting new approaches and attitudes through with to approach such conditions.

By focussing on failures, inconsistencies and the problematics of systems, glitch practices foreground the incommensurability of materials, knowledge, culture - in other words that such things do not, and should not be treated as inputs and outputs within the production of power. Glitch practices have, for some time taken the detritus of technology as their subject; reimagining material cast-offs, marginalised ideas and aesthetics as valuable, despite (and because) they have been deemed ineffective by the matrices of legitimation they existed within. In such a context, glitch practices stand in dynamic tension to the smooth running homogeneity of various systems - corporate, informational, cultural, social - feeding from their trips and mistakes; delineating the cybernetic dream even as they reveal its status as illusion.

A further paralogical aspect of glitch practices is that they are often participatory and based on do-it-yourself (or do-it-together) practices, which in some sense take powers of legitimation away from institutions and corporations. Lyotard argues that through the 'thorough exteriorization of knowledge [...] the old principle that knowledge is indissociable from the training of minds is becoming obsolete...' (op.cit. 4) However, this emphasis on DIY methodologies is often connected with self-taught approaches and motivated by surprise and engagement with the materials. Here, glitch practices are a way to understand technology, culture and aesthetics from a hands-on perspective, forming a heuristic function that displaces the need for institutional legitimation. In this regard glitch practices (and open source values more widely) raise some significant issues for academia - both because they call into question the relevance of academic validation itself, and if this issue is put to one side, because the critical frameworks through which to understand these emergent phenomena necessarily struggles to catch up with such grass-roots participatory practices.

\section{Performativity of Glitch}

Despite the potential of glitch practices, such aesthetics are not immune from recuperation into performative legitimation structures. What remains problematic is that aesthetics - even noisy ones - are determinate - governed by codes and rules of language. Whilst glitch is well placed to reveal the inconsistencies of the system, and temporarily bring about personal or poetic encounter; faced with finite aesthetic outcomes it becomes easy for systems to account in advance for such disturbances and recuperate antagonism into standardised processes. Through over-exposure glitch aesthetics can become 
clichéd and drained of their impact; they lose their ability to provoke when their tactics are aped by more stable, easily accountable fields such as advertising, popular music, and the music technology industry (for example in the production of glitch plug-ins); in short, their sharp shock loses its punch.

Glitch theorists and practitioners already attempt to account for these issues (though conceptualised somewhat differently) through an emphasis on process, 'wild' or 'pure' glitches (Cloninger 10 and Moradi 8 respectively) and the moment(um) of glitch (Menkman). Rosa Menkman discusses this tension in the 'Glitch Studies Manifesto':

...to design a glitch means to domesticate it. When the glitch becomes domesticated, controlled by a tool, or technology (a human craft) it has lost its enchantment and has become predictable. It is no longer a break from a flow within a technology, or a method to open up the political discourse, but instead a cultivation. (7)

Whilst the essence of glitch is an unexpected malfunction, (Motherboard 1) to use it within aesthetic contexts means, in some sense, to prompt - and expect - such malfunctions. If performativity can be aligned with stability and efficiency, a key ambition for Menkman and others is to avoid this trend towards homeostasis and predictability by invoking glitches in the moment(um) or 'in the wild' (Cloninger 10) - through, for example, live performance, or unreliable machines rather than plug-ins and recordings.

Such discourses provide useful concrete examples of tensions between performativity and paralogy in action - playing out the tension between system and unstable rule set; yet there remain questions around the degree to which such strategies solve the problem or simply parallel the notion of
Just-In-Time manufacture. Clearly the tensions between wild and conserved glitches are full of productive antagonisms that, in themselves keep discourses firmly focussed on the assumptions and conventions of such practices: a good indicator of their status as paralogous. But there are other strategies diagrammed by the notion of paralogy that glitch suits very well.

Perhaps the problem here is not the individual instances that might be thought of in terms of glitch and noise practices, but their aggregation into a stabilised genre and defined generic conventions. In all good examples of glitch-art (or any other art for that matter) the subject overflows generic characteristics. In glitch art it's not the noise that is interesting per se, so much as the relation of noise-to-signal (known as the 'equivocation' within Information Theory) that counts: whilst noise is the unifying generic convention, the meaning is derived in how the signal is modulated by it. From this perspective, context becomes the dominating structure, not genre.

To extend the paralogical potential of glitch and noise means to avoid its stabilisation as a genre geared to fulfilling the expectations of the art market, festival circuit, or research institution. What remains of glitch when one leaves behind generic convention? An emphasis on the materiality and limits of media; of a hands-on, tinkering, heuristic approach; on 'doing it yourself', but perhaps more importantly on community practices Do It Together or Do It With Others. Finally, if one substitutes an emphasis on noise for its equivocation, such work can be critiqued and mobilised without resorting to generic conventions. It becomes less important to emphasise the affective shock of glitch, and more important to trace the ecologies and archaeologies of such ruptures. This way of thinking further aligns glitch and noise practices with disciplines such as Media 
Archaeology, already a fruitful connection made by many practitioners but theorised by, amongst others, Garnet Hertz and Jussi Parikka in their Zombie Media project at Transmediale 2011.

\section{Thinkering Approaches}

Many glitch practitioners turn to media archaeological means to do this (Cory Arcangel, Paul DeMarinis, Garnet Hertz, Derek Holzer, Rosa Menkman, Yasunao Tone to name a few), and indeed the overlap between such practices is significant. Archaeology in this case is used in a Foucauldien sense to refer to an epistemological exploration of power and knowledge, specifically through the careful unpicking and disentanglement of objects, practices and discourse to reveal the "layered "unconscious" of technical media culture.' (Parikka 2012:5) Such a focus enables a very direct addressing of the issues around contextualisation, rooting the momentum of glitch within the threads of long standing paralogical histories.

...media archaeology becomes not only a method for excavation of the repressed, the forgotten, or the past, but it extends itself into an artistic method close to Do-It-Yourself (DIY) culture, circuit bending, hardware hacking, and other exercises that are closely related to the political economy of information technology. Media in its various layers embodies memory: not only human memory, but the memory of things, of objects, of chemicals, and circuits. (Hertz \& Parikka 2012:2)

The shared tendency to attempt to unearth the hidden technical, aesthetic and socio-political apparatus' at work, through the hacking, reverse engineering and meddling with media artefacts is a process Erkki Huhtamo see's in the interests of a thinkerer - 'a philosophically oriented artist-archaeologist, always reflecting on the significance of his/her findings and inventions and relating them to wider cultural frames of reference.' (2000:2). The term aptly sums up a handson engagement with technical media that stands as a direct metaphor for the critique and destabilisation required of paralogy. It is a DIY model that emphasises critical reflection and a heuristic approach extending the contextual reach of glitch practices; and moving the shocks and noise of glitch beyond technical channels and into the realm of human engagement. Such a move upsets existing models of legitimation and holds great paralogical potential.

\section{Works cited}

Cloninger, Curt. "GltchLnguistx: The Machine in the Ghost / Static Trapped in Mouths", 1st March. 2011. Web. <http:// lab404.com/glitch/>

DeMarinis, Paul. "Erased Dots and Rotten Dashes, or How to Wire Your Head for a Preservation." Media Archaeology Approaches, Applications, and Implications, Ed. Erkki Huhtamo and Jussi Parikka. London:University of California Press, 2011. 211-239. Print

Hertz, Garnet \& Jussi Parikka, "Zombie Media: Circuit Bending Media Archaeology into an Art Method", Forthcoming in Leonardo Journal. 2013

Halbert, Martin. "Lyotard - The Postmodern Condition", October 11th 2012. Web. <http:// userwww.service.emory.edu/ mhalber/ Research/Paper/pci-lyotard.html> 
Huhtamo, Erkki. "T(h)inkering with Media: The Art of Paul DeMarinis." Resonant Messages: The Art of Paul DeMarinis. Pasadena: Art Center College of Design, 2000. Print.

Lyotard, Jean-Francois. The Postmodern Condition: A Report on Knowledge.

Manchester: Manchester University Press, 1979. Print

Menkman, Rosa. "Glitch Studies Manifesto", 8th November 2011. Web. <http://rosamenkman.blogspot.com>

Motherboard. Glitch Festival and Symposium. 23rd August 2012. Web. <www. liveart.org/motherboard/glitch/gfr_content. html>

Moradi, Iman. Gtlch Aesthetics, BA Thesis for The University of Huddersfield, 2004. Web.

Prior, Andrew "Noise at the Interface", Public Interfaces Conference and Workshop Aarhus University, 2011. Presentation.

Terranova, Tiziana. Network Culture: Politics for the Information Age, London:Pluto Press. 2004. Print.

- "Communication Beyond Meaning: On the Cultural Politics of Information". Social Text, 80 (Volume 22, Number 3), Fall 2004, pp. 51-73

Varnelis, Kazys. Networked Publics, Massachusetts:The MIT Press, 2008. Print accessed October 12th $2012<$ http:// varnelis.net/book/export/html/876> 